\title{
PENGARUH KUALITAS KINERJA TERHADAP KEPUASAN PESERTA PADA KEGIATAN PERJALANAN INSENTIF BANK PERMATA KE EROPA
}

\author{
Fetty Nurmala Rossi \\ AKPAR Jakarta International Hotel \\ Email: fettymice@gmail.com
}

\begin{abstract}
This article explore the relationship between quality of performance towards satisfaction in Incentive Travel context. The research concluded that incentive travel in Europe has overall satisfaction to attendees. Respondents were attendees who get reward from their company (Permata Bank). This study was also conducted to measure whether quality performance sub variable also affects satisfaction. The aim is to see how much attendees get the satisfaction from each sub variable. This study used quantitive descriptive method of multiple regression analysis to identify the effects of quality of performance variables towards participant satisfaction. From the research findings it was revealed that of the four sub variables of performance quality, generic features and comfort amenities had the most influence on determining satisfaction.
\end{abstract}

Keywords: Incentive Travel, Quality of Performance, Satisfaction

\begin{abstract}
Abstrak
Artikel ini membahas tentang hubungan antara kualitas kinerja terhadap kepuasan dalam konteks Perjalanan Insentif Penelitian ini menyimpulkan bahwa perjalanan Insentif di Eropa memiliki kepuasan terhadap keseluruhan untuk peserta. Responden dalam penelitian ini adalah peserta yang mendapat hadiah dari perusahaan mereka yaitu Bank Permata. Penelitian ini juga dilakukan untuk mengukur apakah kinerja sub variabel berpengaruh terhadap kepuasan. Tujuannya adalah melihat seberapa banyak peserta mendapatkan kepuasan dari masing-masing sub variabel. Metode pada penelitian ini menggunakan metode deskriptif serta dukungan data kuantitatif melalui Skala Likert. Adapun analisis data yang digunakan yaitu analisis regresi berganda yang tujuannya melihat pengaruh antara variabel kualitas kinerja terhadap kepuasan peserta. Dari hasil penelitian terungkap bahwa dari empat sub variabel kualitas kinerja, fitur generik dan fasilitas kenyamanan memiliki pengaruh paling besar dalam menentukan kepuasan.
\end{abstract}

Kata Kunci: Incentive Travel, Quality of Performance, Satisfaction

\section{PENDAHULUAN}

Saat ini MICE menjadi salah satu sektor pariwisata yang mendongkrak perkembangan pariwisata di Indonesia. Terutama dari perusahaan atau korporasi yang memiliki rangkaian kegiatan event setiap tahunnya. Rangkaian kegiatan yang sering dilaksanakan adalah Incentive yang diperuntukkan bagi tenaga kerja/ SDM di suatu Perusahaan.

Dalam hal ini, perusahaan membuat kegiatan Incentive untuk memotivasi karyawan karena sudah bekerja keras dan mencapai target.
Tentunya peran Destination Management Company (DMC) sangat penting sekali dalam membuat progam agar menarik. Program insentif harus memiliki keunikan karena peserta adalah spesial di mata perusahaan sehingga peserta dapat merasakan WOW Effect dan memiliki kesan pada setiap program yang dijalankan.

Saat perjalanan insentif, yang diharapkan oleh perusahaan adalah kepuasan tentunya, kepuasan tersebut dapat dicapai apabila keseluruhan program perjalanan insentif sukses. Dalam menentukan kepuasan, diperlukan kualitas dari keseluruhan kegiatan yang dinilai oleh peserta (winners). Sehingga, ketika seseorang sudah mengetahui 
kualitas dari perjalanan tersebut, maka dapat ditentukan apakah peserta tersebut puas atau tidak puas.

Apabila peserta puas dan perusahaan diperlakukan istimewa, maka perusahaan akan kembali lagi memberikan bisnis yang sama dengan kelompok peserta (winners) yang berbeda.

Penelitian ini merupakan observasi terhadap kegiatan Incentive di suatu perusahaan yang menyelenggarakan perjalanan Insentif di Eropa. Oleh karenanya judul pada penelitian ini adalah Pengaruh Kualitas Kinerja terhadap Kepuasan Peserta pada Kegiatan Perjalanan Insentif ke Eropa oleh PACTO DMC.

\section{Tujuan}

Tujuan dari penelitian ini adalah untuk menguji kualitas kinerja dan mengetahui kepuasan individu dalam mengikuti kegiatan Perjalanan Insentif (Incentive Travel).

Penyelidikan kualitas kinerja dan kepuasan tersebut berpotensi dapat membantu untuk mengembangkan isi program perjalanan. Oleh karena itu, penelitian ini akan memberikan pemahaman yang berharga tentang kepuasan wisatawan di Perjalanan Insentif (Incentive Travel)

Pada umumnya, perusahaan memberikan penghargaan tidak hanya perjalanan insentif (Incentive Travel). Ada beberapa jenis penghargaan yang diberikan, yaitu Merchandise, Discount, dan Cash Awards. Akan tetapi, banyak perusahaan lebih memilih Perjalanan Insentif (Incentive Travel) sebagai penghargaan yang paling sukses untuk meningkatkan kinerja karyawan. Fischer (2005:138) memberikan penjalasan Perjalanan Insentif (Incentive Travel) bahwa:

"Incentive travel is that discipline of sales and marketing and management which uses promise, fulfillment and memory of an exceptional travel related experience to motivate participating individuals to attain exceptional levels of achievement in their place of work or education"

Ada beberapa indikator penting ketika merencanakan dan mengatur sebagian besar Perjalanan Insentif, menurut Davidson dan Cope (2003) dalam Gilsdof (2009:9):

1. Experiencing Something Unique
2. Fullfilling one fantasies

3. Being pampered and being treated as Exclusive

4. Having fun doing pleasurable activities

Perjalanan Insentif (Incentive Travel) dibantu oleh agen dalam mengatur program perjalanan yang disebut dengan Destination Management Company (DMC). Tugas DMC yaitu mengatur segala sesuatunya dari mulai transfer, akomodasi hotel serta makan malam yang memiliki tema unik dan bahkan menampilkan selebriti terkenal. Intinya adalah mengurus semua pengaturan perjalanan karena sangat penting untuk keberhasilan.

Dalam hal ini, agar Perjalanan Insentif dapat berhasil, maka perjalanan tersebut dapat diukur berdasarkan kualitas kinerja terhadap kepuasan pada peserta (winners).

Berdasarkan analisis ilmiah, menurut Baker dan Crompton (2000:793) bahwa dalam mengukur kualitas suatu Perjalanan Insentif (Incentive Travel) dapat menggunakan sub variabel kualitas kinerja meliputi generic features, specific entertainment features, information source, dan comfort amenities.

Sehingga, dalam hal ini peneliti akan mengkaitkan kualitas kinerja (quality of Performance) terhadap Perjalanan Insentif (Incentive Travel). Begitu halnya juga terhadap kepuasan. Kepuasan secara umum dapat didefinisikan sebagai perasaan senang atau kecewa seseorang dengan menilai dan membandingkan hasil berdasarkan harapan yang dirasakan dari produk/ jasa. Menurut Oliver (1997:13) mengemukakan kepuasan sebagai:

'Satisfaction is the consumer's fulfillment response. It is a judgment that a product or service feature, or the product of service itself, provided (or is providing) a pleasurable level of consumption-related fulfillment, including levels of under- or over-fulfillment".

Kepuasan dijadikan sebagai respon dari konsumen dimana wisatawan menilai jasa yang disediakan terpenuhi sesuai dengan harapan yang diinginkan. 
Banyak alasan yang menyebabkan wisatawan puas dengan perjalanannya, termasuk dengan kualitas pelayanan yang diberikan seperti infrastruktur, keamanan, kebersihan, suasana alam, dan perlindungan konsumen.

Wisatawan dapat memiliki tingkat kepuasan yang berbeda-beda untuk mengunjungi tujuan tertentu. Dalam penelitian ini kepuasan diukur dengan menggunakan Overall Satisfaction

\section{METODE}

Untuk menjawab pertanyaan penelitian pada tujuan penelitian maka peneliti menggunakan paradigma deskriptif. yang merupakan pencarian fakta dengan interpretasi yang tepat (Whitney, 1960). Metode ini bertujuan untuk menggambarkan sifat sesuatu yang tengah berlangsung pada saat riset dilakukan dan memeriksa sebab-sebab dari suatu gejala tertentu.

Selain itu, juga menggunakan dukungan data kualitatif dan kuantitatif karena untuk menentukan kualitas kinerja dan kepuasan. Pengukuran yang dilakukan melalui Skala Likert yaitu dalam angka 1-5 yang merupakan alat untuk mengukur sikap dari keadaan yang sangat positif, untuk. menunjukkan tingkat penilaian terhadap pertanyaan yang diajukan (Djaali, 2008)

Analisis data dalam penelitian ini menggunakan analisis regresi berganda untuk melihat pengaruh antara variabel bebas (Independent) terhadap variabel terikat (Dependent) Berikut tabel operasionalisasi pada variabel bebas (Independent) dan variabel terikat (Dependent)

Tabel 1. Operasionalisasi Variabel

\begin{tabular}{|l|l|l|}
\hline \multicolumn{2}{|c|}{ INDEPENDENT VARIABLE } \\
\hline \hline & & $\begin{array}{l}\text { Kebersihan kegiatan } \\
\text { perjalanan insentif }\end{array}$ \\
\cline { 3 - 3 } $\begin{array}{c}\text { Quality of } \\
\text { Performance }\end{array}$ & $\begin{array}{l}\text { Merasa aman di setiap } \\
\text { kegiatan }\end{array}$ \\
& Generic & $\begin{array}{l}\text { Keramah tamahan } \\
\text { masyarakat sekitar }\end{array}$ \\
\cline { 3 - 3 } & Feature & $\begin{array}{l}\text { Visual Appearance dalam } \\
\text { kegiatan perjalanan (Suasana } \\
\text { yang ditampilkan di Eropa) }\end{array}$ \\
& $\begin{array}{l}\text { Penyambutan saat } \\
\text { kedatangan di Bandara }\end{array}$ \\
\cline { 3 - 3 } & & Food \& Beverage \\
\hline & & Live Entertainment \\
\hline
\end{tabular}

\begin{tabular}{|c|c|c|}
\hline \multicolumn{3}{|c|}{ INDEPENDENT VARIABLE } \\
\hline & \multirow{5}{*}{$\begin{array}{c}\text { Specific } \\
\text { Entertainment } \\
\text { Feature }\end{array}$} & Program Perjalanan \\
\hline & & Menikmati kota Venice \\
\hline & & Spesial Lunch Program \\
\hline & & $\begin{array}{l}\text { Spesial Gala Dinner } \\
\text { Program }\end{array}$ \\
\hline & & Performance \\
\hline & \multirow{3}{*}{$\begin{array}{l}\text { Information } \\
\text { Source }\end{array}$} & Printed Program \\
\hline & & $\begin{array}{l}\begin{array}{l}\text { Informasi map (pemberi } \\
\text { petunjuk) }\end{array} \\
\end{array}$ \\
\hline & & Signage \\
\hline & \multirow{4}{*}{$\begin{array}{l}\text { Comfort } \\
\text { Amenities }\end{array}$} & \begin{tabular}{|l} 
Kebersihan dan \\
Kenyamanan pada \\
Transportation
\end{tabular} \\
\hline & & \begin{tabular}{|l|} 
Kebersihan dan \\
Kenyamanan pada Hotel
\end{tabular} \\
\hline & & $\begin{array}{l}\text { Pengaturan tempat } \\
\text { duduk }\end{array}$ \\
\hline & & Aksesibilitas lokasi \\
\hline \multicolumn{3}{|c|}{ DEPENDENT VARIABLE } \\
\hline Satisfaction & $\begin{array}{c}\text { Overall } \\
\text { Satisfaction }\end{array}$ & $\begin{array}{l}\text { Kepuasan peserta } \\
\text { perjalanan insentif ke } \\
\text { Eropa }\end{array}$ \\
\hline
\end{tabular}

\section{Teknik Pengambilan Data}

Dalam penelitian ini, instrument yang akan digunakan untuk mengumpulkan data adalah Penyebaran Kuesioner dan Studi Dokumentasi. Menurut Sekaran (2003:223) Kuesioner merupakan teknik pengumpulan data dengan mengajukan pertanyaan kepada responden guna memberikan kuesioner kepada responden secara langsung atau melalui email. Serta studi dokumentasi yaitu menelusuri dokumen-dokumen terkait seperti buku destinasi, informasi itinerary perjalanan insentif, media cetak dan lainnya.

\section{Uji Validitas dan Reliabilitas}

Berdasarkan dari hasil uji validitas yang sudah dilakukan memiliki factor loading lebih besar dari 0. 3. Hal ini dapat diartikan bahwa masing-masing butir pernyataan tersebut adalah valid. Dengan kata lain butir-butir pernyataan tersebut dapat mewakili atau membentuk konstruk dari variabel Perceived Quality Performance. 
Selain itu, Hasil dari Uji Reliabilitas bahwa nilai dari Cronbach's Alpha semua variable lebih besar dari 0. 60. Dengan demikian maka jawaban responden terhadap pernyataan-pernyataan yang digunakan untuk mengukur masingmasing konstruk tersebut adalah konsisten dan konstruk dapat dipercaya (reliable).

\section{HASIL DAN PEMBAHASAN}

Penelitian ini dilakukan di Negara Eropa saat Perjalanan Insentif yang diselenggarakan pada tanggal 28 Maret - 5 April 2014. Data penelitian ini dikumpulkan dengan menyebarkan 90 kuesioner kepada seluruh Peserta Perjalanan Insentif. Penyebaran dilakukan dengan dibantu oleh tourleader masing-masing disetiap bus yaitu satu hari sebelum kepulangan peserta. Dari 90 kuesioner yang disampaikan ke seluruh peserta, kuesioner yang kembali berjumlah 88 dari total jumlah peserta. Semua peserta mengisi data dengan lengkap.

Data menunjukkan bahwa responden pengunjung wanita sebanyak 56 responden atau 63. $6 \%$, dan responden pengunjung pria sebanyak 32 responden atau 36. 4\%. Sebagian besar dari responden berusia antara 41-50 tahun sebanyak 46 peserta.

\section{Statistik Deskriptif}

Hasil penelitian ini menunjukkan bahwa jawaban responden bervariasi karena nilai standar deviasi menjauh dari nol yaitu 0. 2-0. 4.

\section{Uji Asumsi Klasik}

Untuk mengetahui kualitas kinerja terhadap kepuasan peserta pada kegiatan Perjalanan Insentif (Incentive Travel) maka dilakukan Uji Asumsi Klasik sebagai syarat untuk memenuhi pengujian regresi berganda. Uji Asumsi Klasik ada tiga yaitu

1. Uji Multikolinearitas. Uji Multikolinearitas pada penelitian ini dilakukan untuk menunjukkan bahwa antara variabel tidak terjadi hubungan yang sangat kuat atau tidak terjadi hubungan linier yang sempurna. Cara pengujiannya adalah membandingkan Tolerance yang didapat dari perhitungan regresi berganda. Apabila nilai tolerance $<0.1$ maka $\mathrm{H}_{0}$ ditolak terjadi multikolinearitas. Hasil pengujian yang dilakukan masing-masing variabel independen, nilai tolerance untuk mengetahui kualitas kinerja terhadap kepuasan peserta adalah Generic Feature $=0.852$, Specific Entertainment Feature $=0.854$, Information Source $=0.901$, dan Comfort Amenities $=0$. 827. Pada hasil pengujian didapat bahwa keseluruhan nilai tolerance $>0$. 1 sehingga dapat disimpulkan bahwa tidak terjadi multikolinearitas atau variabel independent.

2. Uji Heterokedastisitas. Pada uji ini, diketahui bahwa seluruh variabel independen memiliki niai sig >0. 05 . Generic Feature $=0.100$, Specific Entertainment Feature $=0.978$, Information Source $=0.854$, dan Comfort Amenities $=0$. $297 \mathrm{Maka}_{0} \mathrm{H}_{0}$ gagal ditolak artinya varians error dinyatakan homogeny. Sehingga disimpulkan tidak terdapat permasalahan heteroskedastisitas. Dengan demikian asumsi atas heteroskedastisitas pada model persamaan regresi telah terpenuhi

3. Uji Normalitas. Pada uji ini bertujuan untuk menguji apakah model regresi, variabel terikat dan variabel bebas keduanya mempunyai distribusi normal atau tidak. Model regresi yang baik adalah memiliki distribusi data normal atau mendekati normal (Ghozali, 2007). Berdasarkan hasil pengujian normalitas residual, diketahui bahwa residual model persamaan regresi memiliki nilai asymp. sig. $0.211>$ alpha 0 . 05. Maka $\mathrm{H}_{0}$ gagal ditolak, artinya sebaran nilai residual pada model persamaan regresi dinyatakan berdistribusi normal.

\section{Uji Regresi Berganda}

Menurut Ghozali (2005) uji koefisien determinasi adalah sebuah pengujian yang dilakukan untuk mengetahui kemampuan variabel indepen dengan menjelaskan variasi kontribusi variabel dependen yang diukur dengan persentase. Pengujian koefisien determinasi digunakan untuk menjelaskan seberapa besar variasi variabel dependen dapat dijelaskan oleh variasi dari seluruh variable independen. Uji koefisien determinasi diamati melalui nilai adjusted $\mathrm{R}^{2}$. 
Dari hasil pengujian diketahui koefisien determinasi yang dilihat dari nilai Adj. $\mathrm{R}^{2}$ adalah 0. 227 Artinya 22. 7\% variasi dari variabel dependen satisfaction dapat diprediksi dari kombinasi seluruh variabel independen comfort amenities, spesific entertainment feature, generic feature dan information source. Sedangkan sisa nya sebesar $77.3 \%$ merupakan faktor - faktor lain yang tidak diikutsertakan dalam model penelitian.

\section{Uji F (Uji Serentak)}

Uji serentak atau uji simultan dilakukan untuk menggambarkan seberapa jauh pengaruh variabel independen secara bersama-sama dalam menerangkan variable dependen.

Berdasarkan data yang terjadi, Pengujian secara serentak menghasilkan nilai $\mathrm{F}$ statistic sebesar 6,095 dengan nilai sig. 0,000 < alpha 0,05. Maka Ho ditolak, artinya secara serentak seluruh variabel independen yaitu comfort amenities, spesific entertainment feature, generic feature dan information source. berpengaruh secara signifikan terhadap kepuasan peserta insentif.

\section{Hasil Pengujian Hipotesis dan Pembahasan}

Pengujian hipotesis dilakukan dengan menggunakan analisis regresi berganda. Tujuan dari metode ini adalah untuk memprediksi perubahan-perubahan dalam variabel terikat (dependent variable) dikaitkan dengan perubahan-perubahan yang terjadi dalam sejumlah variabel bebas (Independent variable). Adapun batas toleransi kesalahan $(\alpha)$ yang digunakan adalah 5\% (0. 05). Hasil pengujian hipotesis dengan membandingkan antara nilai $\mathrm{t}$ dengan nilai estimasi koefisien beta $(\beta)$

Pada hipotesa pertama yaitu menguji Sub variabel generic features secara langsung memberikan pengaruh positif dan significant terhadap Kepuasan Peserta Insentif sebesar 0. $009<0$. 05 yang dapat diartikan bahwa terdapat pengaruh generic features terhadap kepuasan peserta insetif. Sementara nilai Beta adalah 0,522 menunjukan bahwa besar dan arah dari pengaruh dari variabel generic features terhadap Kepuasan Peserta Insetif adalah positif atau searah
Tabel 2. Hasil Pengujian Hipotesis 1

\begin{tabular}{|c|c|c|c|c|}
\hline & Hipotesis & $\beta$ & $\begin{array}{c}\text { p- } \\
\text { value }\end{array}$ & Keputusan \\
\hline H1 & $\begin{array}{l}\text { Dimensi generic } \\
\text { features secara } \\
\text { langsung } \\
\text { memberikan } \\
\text { pengaruh yang } \\
\text { positif dan } \\
\text { signifikan } \\
\text { terhadap } \\
\text { Kepuasan Peserta } \\
\text { Insentif }\end{array}$ & $\mathbf{0 , 5 2 2}$ & 0,009 & $\begin{array}{c}\text { H1 } \\
\text { Didukung }\end{array}$ \\
\hline
\end{tabular}

Peserta puas dengan pelayanan yang diberikan melalui variabel generic feature yaitu dari segi faktor kebersihan, keamanan, keramah tamahan guide tourleader penduduk setempat, pertunjukkan secara langsung live entertainment), tampilan secara umum keseluruhan incentive (Visual Appearance Incentive Travel). Kegiatan tersebut dikombinasikan dengan atraksi dimana peserta juga harus ikut bergabung dalam pertunjukkan tersebut

Pada hipotesa kedua yaitu menguji Sub variabel specific entertainment feature secara langsung memberikan pengaruh negatif terhadap kepuasan Peserta Insentif sebesar 0. 901>0. 05. Hal ini terjadi dikarenakan perbedaan karakteristik peserta.

Tabel 3. Hasil Pengujian Hipotesis 2

\begin{tabular}{|c|c|c|c|c|}
\hline Hipotesis & $\boldsymbol{\beta}$ & $\begin{array}{c}\text { p- } \\
\text { value }\end{array}$ & Keputusan \\
\hline \hline & $\begin{array}{c}\text { Dimensi specific } \\
\text { entertainment } \\
\text { fetaure secara } \\
\text { langsung } \\
\text { memberikan } \\
\text { mengaruh yang } \\
\text { pengan } \\
\text { positif dan signifikan } \\
\text { Kepuasan Peserta } \\
\text { Insentif }\end{array}$ & $\mathbf{0 , 0 1 8}$ & $\mathbf{0 , 9 0 1}$ & H2 Tidak \\
& & & \\
\hline
\end{tabular}

Pada Hipotesa ketiga yaitu menguji Sub variabel information source secara langsung memberikan pengaruh negatif terhadap Kepuasan Peserta Insentif sebesar 0. 289>0. 05. 
Tabel 4. Hasil Pengujian Hipotesis 3

\begin{tabular}{|c|c|c|c|c|}
\hline Hipotesis & $\boldsymbol{\beta}$ & $\begin{array}{c}\text { p- } \\
\text { value }\end{array}$ & Keputusan \\
\hline \hline H3 & $\begin{array}{c}\text { Dimensi information } \\
\text { sourcen secara } \\
\text { langsung memberikan } \\
\text { pengaruh yang } \\
\text { positif dan signifikan } \\
\text { terhadap Kepuasan } \\
\text { Peserta Insetif }\end{array}$ & $\mathbf{0 , 1 9 6}$ & $\mathbf{0 , 2 8 9}$ & H3 Tidak \\
Didukung \\
\hline
\end{tabular}

Dalam hal ini, peserta khususnya orang Indonesia, Jika dilihat pada karakteristik bahwa orang Indonesia tidak terlalu memperhatikan informasi seperti sejarah suatu daerah, arahan petunjuk, program yang intinya berkaitan dengan sebuah informasi dan perjalanan ini juga dibantu oleh tourleader serta guide dalam memberikan informasi.

Pada Hipotesa keempat yaitu menguji Sub variabel comfort amenities terhadap kepuasan peserta insentif bahwa nilai signifikan untuk hubungann antara variabel comfort amenities terhadap Kepuasan Peserta Insetif adalah sebesar $0,027<0,05$ yang dapat diartikan bahwa terdapat pengaruh comfort amenities terhadap Kepuasan Peserta Insetif. Sementara nilai Beta adalah 0,327 menunjukan bahwa besar dan arah dari pengaruh dari variabel comfort amenities terhadap Kepuasan Peserta Insetif adalah positif.

\section{Tabel 5. Hasil Pengujian Hipotesis 4}

\begin{tabular}{|c|c|c|c|c|}
\hline & Hipotesis & $\boldsymbol{\beta}$ & $\begin{array}{c}\text { p- } \\
\text { value }\end{array}$ & Keputusan \\
\hline $\mathrm{H} 4$ & $\begin{array}{l}\text { Dimensi comfort } \\
\text { amenities secara } \\
\text { individu dan } \\
\text { langsung } \\
\text { memberikan } \\
\text { pengaruh yang } \\
\text { positif dan } \\
\text { signifikan } \\
\text { terhadap } \\
\text { Kepuasan Peserta } \\
\text { Insetif }\end{array}$ & $\mathbf{0 , 3 2 7}$ & $\mathbf{0 , 0 2 7}$ & $\begin{array}{c}\mathrm{H} 4 \\
\text { Didukung }\end{array}$ \\
\hline
\end{tabular}

Dalam konteks perjalanan insentif (Incentive Travel) kenyamanan merupakan hal yang penting untuk menikmati sebuah perjalanan. Kenyamanan fasiltas hotel yang diberikan adalah hotel standar bintang lima, kemudian transportasi yang diberikan juga sesuai standar pariwisata, akses dari satu tempat ke tempat yang saling berdekatan misalnya lokasi restaurant dengan tempat wisata, serta pengaturan tempat duduk saat gala dinner membuat peserta nyaman. Sehingga diperjalanan insentif inilah, peserta merasakan kenyamanannya.

Kemudian pada hipotesa kelima, yaitu melihat keseluruhan kualitas kinerja terhadap kepuasan peserta menunjukkan nilai signifikan untuk hubungan antara Quality of Performance secara bersama-sama terhadap Kepuasan Peserta Insetif adalah sebesar $0.000<0.05$ sedangkan Beta adalah 0. 190 yang menunjukan bahwa besar dan arah dari pengaruh dari variabel Quality of Performance secara bersama-sama terhadap kepuasan Peserta Insentif adalah positif.

Tabel 6. Hasil Pengujian Hipotesis 5

\begin{tabular}{|c|c|c|c|c|}
\hline Hipotesis & $\begin{array}{c}\text { Adjue- } \\
\text { ted R2 }\end{array}$ & $\begin{array}{c}\text { p- } \\
\text { value }\end{array}$ & Keputusan \\
\hline \hline H5 & $\begin{array}{c}\text { Quality of } \\
\text { Performance secara } \\
\text { bersama-sama } \\
\text { memiliki hubungan } \\
\text { yang significant } \\
\text { terhadap kepuasan } \\
\text { peserta insentif }\end{array}$ & $\mathbf{0 , 1 9 0}$ & $\mathbf{0 , 0 0 0}$ & $\begin{array}{c}\text { H5 } \\
\text { Didukung }\end{array}$ \\
\hline
\end{tabular}

Hal tersebut membuktikan bahwa seluruh peserta secara keseluruhan puas dengan pelayanan kualitas yang diberikan, meskipun dari hasil data dimensi information source dan specific entertainment features memberikan pengaruh negatif. Kepuasan peserta dilihat dari kualitas pelayanan seperti akomodasi, transportasi yang ditempati selama perjalanan, keramahtamahan guide, penduduk lokal, serta program yang dijalankan sehingga membuat peserta merasa nyaman dan terlayani dengan baik.

\section{KESIMPULAN}

Penelitian ini menunjukkan hasil bahwa sub variabel kualitas kinerja ada yang memiliki pengaruh dan tidak berpengaruh. Generic feature dan comfort amenities menunjukkan terdapat pengaruh terhadap kepuasan peserta pada kegiatan 
insentif. Hal ini terjadi karena kenyamanan yang diiginkan peserta terpenuihi dari segi fasilitas kenyamanan hotel, transportasi, restoran. serta aksesibilitas yang berdekatan. Tidak hanya itu, generic feature dan comfort amenities menunjukkan bahwa kedua sub variabel tersebut merupakan faktor terbesar untuk memperkuat kepuasan peserta Kedua sub variabel inilah yang membangkitkan perasaan senang dan meningkatkan kepuasan dalam perjalanan insentif (Incentive Travel) dan menurunkan tingkat keluhan.

Sedangkan Specific Entertainment Feature dan Information Source tidak memilki pengaruh terhadap kepuasan peserta.

Bila dilihat dari hasil penelitian, secara keseluruhan kualitas kinerja (Quaility of Performance) memiliki pengaruh terhadap kepuasan peserta pada kegiatan perjalanan insentif. Sehingga, persepsi peserta dalam hal ini merasa terpuaskan akan keseluruhan program perjalanan yang dilakukan dari awal sampai akhir.

Untuk menciptakan kualitas insentif wisata yang baik, peran DMC dapat memberikan pelayanan yang unggul dalam differensiasi dan inovasi produk. Sebab, dengan memberikan pelayanan yang excellent dibarengi dengan differensiasi dan inovasi produk wisatawan tidak akan pernah bosan untuk datang kembali.

Untuk penelitian selanjutnya, ada baiknya dapat menambah lokus penelitian destinasi yang berbeda dan berlokasi di Indonesia seperti Lombok atau Solo serta dapat menambah variabel lain terhadap tourist loyalty.

\section{DAFTAR PUSTAKA}

Baker, D. A. \& Crompton, J. L. 2000. Quality, satisfaction, and behavioral intentions. Annuals of Tourism Research. 27, 785-804.
Chen, W. C, Lee,C. F, Lin, L. Z. 2012. Investigating factor affecting festival quality: A Case study of Neimen Song Jhen Battle Array Taiwan. Journal of Marketing Management. 36(2), 43-54.

Fisher, John G. 2005. How to run successful incentive schemes, third edition, Kogan Page Limited. London.

Gilsdorf,. J. 2009 A Potential Destination for Incentive Travelers. Islandia Sigillum University.

Morrisson, Allaistar M. 2010. Hospitality and Travel Marketing: The Distribution of Mix and Travel Made-Incentive Planner

Prayag, Girish. 2009. Tourist evaluations of destination of destination image, satisfaction, and future behavioral intentions-the case of mauritus. Journal of Travel and Tourism Marketing. 26,836-853

Sanchez Rebul, M-V, Rudchenko, Martin. 2018. The Antecedents and Consequences of Customer Satisfaction in Tourism; A Systematic Literarture Review.

Salleh, M. Omar K \& Yaakop A. 2013. Tourist Satisfaction in Malaysia. International Journal of Business and Social Science Vol 4 No 5

Severt K. 2013. Channel Incentive Travel Programs: Stakeholders Perceptios and Indicators of satisfaction and loyalty based on the Incentive Travel Experience. J Tourism Res Hospitality. 2:3, 1-12

Skogland, L. \& Siguaw, J. A. 2004. Are your satisfied customer loyal? Cornell Hotel and Restaurant Administration Quarterly. 45,221-234

Yuan, J. \& Jang, S. 2008. The effects of quality and satisfaction on awareness and behavioral intentions: Exploring the role of a wine festival. Journal of Travel and Research. 46(3), 279-28 
Journal of Tourism Destination and Attraction 